\title{
One year on
}

\author{
Elizabeth Kay, EBD Editor
}

\section{A} year on. A whole twelve months later. A full 365 days further into our lives than when we first heard those potentially fatal words... COVID-19. COVID$19 . .$. a virus. And at first many laughed it off - 'just a cold', 'just a nasty dose of flu,' the cynics said, a fuss about not much...

Now, a year later, more than 120,000 people in the UK, and countless numbers across the world are dead. Had we been able to control or eradicate, or even effectively manage the virus, they would not be. In addition to this hideous death toll, livelihoods have been lost, futures put on hold, a cohort of children have missed vital education and exams, and depression has taken hold of many. Irrevocable mental health damage has been inflicted on thousands and thousands of people and the economy is kept afloat through borrowing, which will affect not only our children, but our children's children and beyond.

Yet, we battle on. Dentists have found ways to keep their practices running, people have found new interests and excitements. We have learnt that a holiday (or three) abroad each year isn't a right, or even the necessity that we used to think it was. We have learnt to use our vehicles less, communicate more, care more, be kinder. And perhaps most importantly, we have learnt to truly appreciate the amazing people who, no matter what, keep serving us in shops, collecting our rubbish, caring for the most vulnerable and needy. At last, the world has woken up to the commitment, the tenacity, the brilliance, and the truly vocational dedication of those working on the front line of health services.

One day, hopefully soon, as the vaccine rolls out, we will look back on the past year with not only horror, but with a degree of nostalgia for that sense of unity and appreciative 'Dunkirk spirit' that COVID19 , when it started, gave us. One day, in the further future, 2020 will be a time about which old folk talk, with a degree of pride in their own survival, and our stoicism in the face of such adversity. They will tell tales of extraordinary heroism to their children.
At the moment, however, simple acts such as travelling somewhere nice for the day, or seeing other people just for the pleasure of being with them, or heading off to work in the morning, now feel strange and slightly alien. Our lives have been shrunk to our immediate environs largely within the walls of our homes, and the thought of walking freely, maskless among others, now seems scary, and the ubiquitous hugging and kissing of acquaintances, now seems utterly foolhardy and potentially dangerous.

We have assimilated, and made normal, entirely new behaviours. Entirely novel assumptions have become part of the texture of our everyday lives. Hand sanitisers are carried by all and are available on every shop checkout counter. We no longer raise a cynical eyebrow at people who walk about dressed in surgical masks, and we treat all objects touched by others with extreme caution. These are our new norms. In fact, it feels jolly odd to have hands that are anything but freshly washed; one feels naked and unprotected without a face mask; and previous physicality in our greetings to each other would now be considered rather crass, and possibly rude.

So we have changed and we must continue to change, because as we pull ourselves carefully through and out of the crisis of the pandemic, as the virus is brought under control, there will be further challenges ahead. For example, the psychological effects of our enforced social isolation, the impending global economic problems, and exploring the true depths of emotional trauma felt by those who have lost loved ones will be the next hurdles we face as we come to truly understand the worldwide impact of the pandemic.

Human beings are herd animals. We like to be part of group. We are also planners

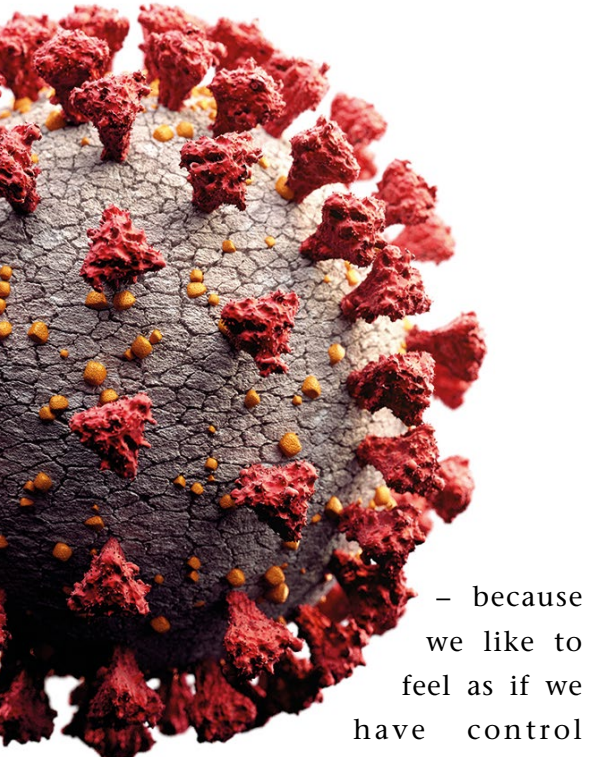

over the events in our lives. But the current circumstances have meant that the controls and the natural behaviours that 'normally' run our lives are no longer here. And that, I believe, is what we primarily crave when we say we want things to be 'back to normal'. Having been rendered totally helpless by something of which we were unaware, and unprepared for, we long to feel in control once again. That is certainly true in dentistry.

We are not yet through this devastating pandemic. But one day soon we will be, and in the meantime we must continue to hunker down and do our best. We must continue to support each other, and we must continue to be patient. In addition, we must continue to concentrate on, and strive to understand more about this virus and what has happened to us. We must seek to truly grasp the social and economic impacts of the disease, on our profession, as well as the world. We absolutely must properly unpick and comprehend the many issues that we in dentistry have faced in the last year. To that end, the next issue of Evidence-Based Dentistry will, once again, be a COVID-19 issue, in which we will do our utmost to present the best evidence available about how we might proceed through the next phase of the pandemic.

Evidence-Based Dentistry (2021) 22, 4. https://doi.org/ 10.1038/s41432-021-0167-1 